\title{
Litigation in tobacco control: past, present and future
}

\author{
Suzanne Zhou (10, ${ }^{1}$ Evita Ricafort, ${ }^{2}$ Davi Bressler, ${ }^{3}$ Rachel Kitonyo Devotsu ${ }^{4}$
}

${ }^{1} \mathrm{McC}$ abe Centre for Law and Cancer, Melbourne, Victoria, Australia

${ }^{2} \mathrm{McC}$ abe Centre for Law and Cancer, Manila, Philippines ${ }^{3}$ Attorney General's Office of Brazil, Brasilia, Brazil ${ }^{4}$ McCabe Centre for Law and Cancer, Nairobi, Kenya

\section{Correspondence to} Ms Suzanne Zhou, McCabe Centre for Law and Cancer, Melbourne, VIC 3004, Australia; Suzanne.Zhou@mccabecentre. org

Received 18 June 2021 Accepted 22 September 2021

\section{ABSTRACT}

This paper reviews progress in tobacco litigation since Tobacco Control's founding 30 years ago, with a focus on cases which are ongoing or recently decided. Litigation in tobacco control falls into several classes: legal challenges brought by the tobacco industry to block implementation of tobacco control measures, public interest litigation brought by civil society to push for higher standards of implementation of tobacco control measures and liability litigation by governments and individuals to hold the tobacco industry accountable for the harm it causes. In each class of cases, there are a number of major case studies which show the importance of international frameworks, including most significantly the WHO Framework Convention on Tobacco Control, to tobacco litigation.

\section{INTRODUCTION}

The legal landscape for tobacco control has undergone dramatic changes since Tobacco Control was founded 30 years ago. Thirty years ago, there was no international treaty on tobacco control. Many legislative interventions which are now commonplace, such as graphic health warnings and smokefree laws, had only just begun to be proposed and implemented. Nor were there the same kind of networks to support countries to implement new tobacco control laws as exist today.

Tobacco litigation, too, has undergone a transformation over the last decades. A key feature of this transformation has been the internationalisation of tobacco control litigation. Many types of tobacco control litigation, whether legal challenges brought by tobacco companies in an attempt to block new laws and regulations, public interest litigation brought by civil society to push for higher standards or litigation brought against the tobacco industry itself to hold them accountable for the tobacco epidemic, now raise questions of global significance. Constitutional cases now cite the WHO Framework Convention on Tobacco Control (FCTC); litigation takes place under international trade and investment law or international human rights law, and litigation strategies are now shared across countries by transnational networks of lawyers.

This piece surveys some of these developments, focusing on litigation with broader implications for public health policy. It looks at three key types of litigation-legal challenges brought to prevent, delay or weaken tobacco control measures; public interest litigation brought to strengthen implementation of tobacco control; and liability litigation brought to hold the tobacco industry accountable for its actions. Each of these shows the impact of global frameworks, including most significantly the WHO FCTC, on the development of tobacco control litigation over the last decades, and the increasing significance of litigation to advancing tobacco control.

\section{LEGAL CHALLENGES TO IMPLEMENTATION}

A large part of recent litigation on tobacco control is made up of legal challenges by the tobacco industry to prevent, delay or weaken tobacco control laws, with the database tobaccocontrollaws.org showing almost 300 legal challenges brought against government measures since the WHO FCTC's entry into force in $2005 .^{12}$ This reflects partly the progress that has been made in implementing tobacco control measures-many countries have implemented new tobacco control measures following their ratification of the WHO FCTC, and the tobacco industry has reacted by using litigation as part of its strategy to interfere with the implementation of tobacco control laws and regulations. Often, these challenges aim to tie up resources, dissuade other governments from following an example or raise the costs of implementation, and many therefore target the world's first tobacco control measures, such as Australia's 2011 tobacco plain packaging laws or large graphic health warnings in Uruguay, Thailand and Sri Lanka. ${ }^{3}$ Recent years have seen a number of landmark cases dismissing such challenges by the tobacco industry, and in the process affirming governments' right to prioritise public health over the commercial interests of the private sector.

\section{Trade and investment: Australia and Uruguay}

In the last decade in particular, one notable aspect of this litigation has been the rise and fall of trade and investment litigation as a means of challenging tobacco control measures, exemplified by disputes brought against Uruguay's large graphic health warnings and brand variant restrictions, ${ }^{4}$ and Australia's plain packaging laws. ${ }^{5}$ Earlier trade cases had certainly been brought, including a challenge brought by the USA against an import ban on cigarettes in Thailand ${ }^{7}$ and a challenge brought by Indonesia against a flavour ban in the USA that covered predominantly imported clove cigarettes, but (at the time) not predominantly US-produced menthol cigarettes. ${ }^{8}$ However, what was different about Australia and Uruguay's measures is that the challenges to them did not allege any kind of discrimination. Unlike a discrimination case, where the key issue is whether domestic and imported products are treated comparably, and the extent of regulation is not a concern, these newer legal challenges essentially attacked the evidence supporting Australia and Uruguay's tobacco control measures, and argued that the measures were incompatible with international intellectual property protections, as a strategic attempt to try to dissuade others from 
following the example by threatening expensive litigation at the international level. They therefore raised much more fundamental questions about the tension between economic liberalisation and public health, and about the space that governments have to implement life-saving tobacco control policies.

The dismissal of all the legal challenges brought against Australia and Uruguay's measures is therefore a landmark development, both for tobacco control and for public health and trade more broadly. In Australia, legal challenges to plain packaging in the World Trade Organization, ${ }^{6}$ under the 1993 Hong KongAustralia bilateral investment treaty, ${ }^{5}$ and in the High Court of Australia were all decided in favour of Australia. ${ }^{9}$ In Uruguay, the tribunal constituted under the 1988 Switzerland-Uruguay bilateral investment treaty rejected comprehensively the challenge brought by Philip Morris companies and their Uruguayan subsidiary. ${ }^{4}$

These trade and investment disputes clarify the space under trade and investment agreements to regulate for public health. Importantly, they confirm that trademark laws (and other forms of intellectual property) do not prevent the regulation of packaging and labelling nor the prohibition of advertisingtrademarks granting only a right to prevent third parties from infringing a trademark, not a right to prevent the state from regulating its use. They have also made statements that are important to countering tobacco industry interference more generally, including by rejecting tobacco industry arguments about the evidence (and in many cases chastising attempts to confound the evidence), affirming the importance of the WHO FCTC as evidentiary support and clarifying that countries with limited resources to develop local evidence can rely on the experiences of others. ${ }^{1011}$

\section{Domestic and regional court cases}

While the trade and investment cases may be some of the most high-profile legal challenges, litigation in domestic and regional courts remains the most common form of legal challenge. Here, too, we have seen a number of landmark cases rejecting the arguments of the tobacco industry and affirming states' right to adopt and implement tobacco control measures in accordance with the WHO FCTC.

While a complete review of these legal challenges is outside the scope of this paper, a few case studies show some of the issues involved in this kind of litigation.

In 2019, the Supreme Court of Kenya dismissed a challenge by British American Tobacco (BAT) to its Tobacco Control Regulations, finding that BAT had not had any of its procedural rights to participate infringed during the lawmaking process, that the conflict of interest provisions in the law did not discriminate against BAT given that it was reasonable to protect public health policies from tobacco industry interference, that there was no violation of intellectual property rights and that there was a sound legal basis to require tobacco companies to pay $2 \%$ of the value of tobacco products manufactured or imported in each financial year into a tobacco control fund. ${ }^{12}$ In Uganda, similarly, the Constitutional Court of Uganda rejected a challenge brought by BAT Uganda against its Tobacco Control Act. Notably, the Ugandan court emphasised that the Tobacco Control Act advances the rights to life and health, while also situating BAT's challenge within a broader pattern of the tobacco industry using litigation to intimidate countries and prevent critical public health policies from being adopted. ${ }^{13}$

Several countries have had victories affirming their ability to adopt large graphic health warnings under Article 11 of the
WHO FCTC. In Thailand, the Supreme Administrative Court ruled that the implementation of graphic health warning regulations should not be suspended as sought by the tobacco industry, as the requirements were not beyond the scope of the law and were issued to protect the people and the youth. ${ }^{14}$ In Sri Lanka, the Court of Appeal upheld graphic health warning regulations and looked at international evidence on the effectiveness of pictorial health warnings. The court noted that it was taking on a 'global point of view', considering that pictorial warnings are accepted and adopted all over the world. The court also took the WHO FCTC and the Article 11 Guidelines into account and emphasised that domestic law should be interpreted in harmony with Sri Lanka's international commitments. ${ }^{15}$ In Europe, the unsuccessful legal challenge to the European Union's (EU) Tobacco Products Directive both upheld EU-wide graphic health warnings, among other measures, and paved the way for many European countries to adopt plain packaging. ${ }^{16}$

Each of these cases is significant in allowing tobacco control laws to move ahead, and in contributing to a growing body of case law affirming that public health should take priority over the commercial interests of the tobacco industry, and in many cases, contributing to progressive interpretations of the right to health which advance the protection of the right in other contexts as well. ${ }^{17}$

\section{PUBLIC INTEREST LITIGATION}

Although these are fewer in number than industry-brought litigation, there are also many examples of cases brought by civil society to push for higher standards. These have taken two forms. In countries where international treaties can be directly enforced in domestic courts, civil society have brought cases to compel implementation of the WHO FCTC. In other cases, civil societies have argued that obligations under the right to life or right to health require action on tobacco control.

In relation to actions directly invoking the WHO FCTC, in the Netherlands, civil society organisations brought a case arguing that the Netherlands had not complied with its obligations under Article 8 of the WHO FCTC, because its smoke-free law had exceptions that were inconsistent with the recommendation in the Article 8 implementation guidelines for 100\% smoke-free public places. The Supreme Court, as well as the lower courts, ordered the government to adopt a smoke-free law that did not contain such exceptions, finding that Article 8 should be interpreted in light of the recommendation in the guidelines that only $100 \%$ smoke-free laws were effective. ${ }^{18}$ This litigation clarifies that, in addition to providing technical guidance, the WHO FCTC guidelines are an important aspect of interpreting the obligations under the WHO FCTC itself.

In relation to human rights examples, in India, the 2001 case of Murli S Deora established that failing to provide a smoke-free environment by banning smoking in public places was a violation of the right to life. ${ }^{19}$ More recently, in the case of Love Care Foundation $v$ Union of India, the right to life and the WHO FCTC read together have been used to successfully argue that the government should undertake a feasibility study into plain packaging, ${ }^{20}$ while in a case pending before the National Green Tribunal, advocates argue that the failure to prevent cigarette butt pollution violates environmental laws. ${ }^{21}$ Public interest litigation sits alongside other ways in which civil societies have used human rights law to advance tobacco control. In the legal challenge brought by BAT in Uganda, mentioned above, the Center for Health, Human Rights and Development intervened in support of the government, arguing that the tobacco control 
law promoted the right to health, ${ }^{13}$ while advocates have also submitted shadow reports before human rights committees under international human rights treaties, such as in Argentina (a non-party to the WHO FCTC), where a coalition of women's groups and tobacco control groups argued that Argentina had failed to protect women's rights to health by failing to regulate gender-targeted tobacco advertising. ${ }^{22}$

\section{ARTICLE 19 LITIGATION}

Litigation against the tobacco industry has been a long-standing feature of the law in tobacco control. Examples of such litigation include healthcare cost recovery litigation in the USA, which led to a 'master settlement agreement' with major tobacco manufacturers to compensate US states for the cost of tobacco-related illness, ${ }^{23}$ antiracketeering litigation by the US Department of Justice to hold the industry accountable for deceiving the public in relation to the harms caused by tobacco ${ }^{24}$ and personal injury litigation brought by individuals around the world seeking compensation for illness (and in some cases death) caused by the tobacco industry. ${ }^{25}$ Much of this litigation has been critical to exposing the behaviour of the tobacco industry over decades to prevent action on public health.

In recognition of the importance of litigation by both individuals and governments against the tobacco industry, Article 19 of the WHO FCTC requires that parties 'consider taking legislative action or promoting their existing laws, where necessary, to deal with criminal and civil liability, including compensation where appropriate'. However, this is not an easy task for countries, as political will, legal ground for the court action and the challenge of engaging big conglomerates in court play a big part in the success of the litigation. To date, few countries have successfully engaged in attempts to hold the tobacco industry liable.

In the last few years, there have been major developments in litigation to hold the tobacco industry accountable in its role in the global tobacco epidemic. These include criminal complaints in the Netherlands ${ }^{26}$ and France, ${ }^{27}$ which, although not yet resulting in successful prosecutions, have expanded public awareness of the harm the tobacco industry causes. They also include civil liability judgements in favour of persons affected by smoking-related illnesses, ${ }^{28}$ as well as healthcare cost recovery actions currently in progress against the industry.

One of the most recent initiatives in this matter comes from Brazil, a big producer and consumer of tobacco and a country with one of the most extensive free and universal healthcare systems globally. The Brazilian public healthcare system is financed by the whole population, and the damages of tobaccorelated diseases impose a tremendous burden on all society.

In light of that fact, the Attorney General's Office of Brazil, in May 2019, filed a lawsuit against the country's biggest tobacco manufacturers, including the Brazilian subsidiaries and the headquarters Philip Morris International and BAT. ${ }^{2930}$ The case shines a light on the liability of transnational companies and how all economic groups have to be held accountable for their actions.

The lawsuit describes the wrongdoings of the industry through decades (denial of the addictiveness and harms of the product, marketing for children, on others) and shows how these conducts had an impact on Brazil's population, even if committed by the headquarters. Brazil's case is in its early stages, but serves as an instrument to promote awareness and expose the tobacco industry on a global scale, and may well be a landmark litigation to exact liability from the industry. The experience of Brazil should encourage countries to seek guidance and support to analyse the possibility of entering similar endeavours under Article 19.

By exposing the industry's practices, lawsuits filed under Article 19 can help fulfil other WHO FCTC rules as well. Discussions about cases can raise public awareness, develop knowledge about how the government must relate to tobacco companies and protect the population from new products claimed to be less harmful, just as 'light' cigarettes were portrayed years ago.

\section{ROLE OF THE WHO FCTC IN THIS LITIGATION}

From the above, we can see the significance of international laws and policy frameworks to much of this litigation, both as a forum for such litigation in the case of trade and investment agreements, and as norms which are applied in domestic courts, in the case of arguments on human rights or intellectual property. The WHO FCTC in particular has had a remarkable impact on shaping many aspects of tobacco control litigation. ${ }^{31} 32$ It has:

- Provided a basis for pushing for higher standards of tobacco control implementation.

- Helped integrate tobacco control into human rights agendas, including through the WHO FCTC's recognition in its preamble of the links between human rights and tobacco control.

- Provided evidentiary support in trade and investment cases, either in terms of the scientific evidence, or to demonstrate international practice or consensus.

- Supported the legal basis of tobacco control measures.

- Supported the characterisation of a measure as a public health measure or as reasonable/proportionate.

- Demonstrated why it is necessary to limit certain commercial rights and interests.

More broadly, the WHO FCTC has helped support countryto-country sharing of information relating to litigation, provided a forum for networks to be built between civil societies, created institutions to provide technical support to countries such as the Knowledge Hub on Legal Challenges, ${ }^{33}$ facilitated related work on litigation through civil society organisations such as the Campaign for Tobacco-Free Kids' International Legal Consortium and Corporate Accountability International and provided tools for parties such as the Article 19 liability toolkit. ${ }^{34}$ And of course, many of these cases relate to measures which were undertaken to implement the WHO FCTC, or in accordance with its obligations on liability under Article 19, so the treaty itself, and support to countries to implement the treaty through initiatives such as the FCTC 2030 project, has inherently shaped the course of much of this litigation.

\section{CONCLUSION}

Litigation in tobacco control continues to evolve, with the tobacco industry and its allies in particular shifting many of its legal challenges to the treatment of tobacco products under COVID-19 lockdown laws, ${ }^{35}$ challenges to 'tobacco-free generation laws ${ }^{36}$ and cases involving the regulation of e-cigarettes and other novel tobacco products, as well as product regulation more generally. ${ }^{37}$ Likewise, governments and civil societies continue to adapt their use of litigation as a tool to advance public health, with liability cases such as those in Brazil and France mentioned above still in their early stages. However, the existing body of tobacco control litigation has made a major contribution to the development of international and domestic public health law, and will no doubt continue to touch on important systemic questions, including the responsibilities of powerful commercial actors, the duties of states to protect public health and the rights of people to life and 
health, in the face of an industry that continues to kill 8 million people a year.

\section{What this paper adds}

- This paper examines tobacco litigation across all three categories of legal challenges brought by industry, public interest litigation by civil society and litigation to hold the tobacco industry accountable.

- The paper analyses several major recent cases and draws lessons from them for the role of law and international cooperation in tobacco control.

\section{Twitter Suzanne Zhou @zhousuzanne}

Acknowledgements The authors thank Keith Lu for editorial assistance in preparing the manuscript and references.

Contributors The authors jointly conceptualised and developed the outline of the paper. SZ drafted the sections on trade and investment and collated contributions from the author team. ER, RKD and SZ drafted the sections on domestic and regional court cases. DB drafted the section on Article 19 litigation in Brazil. All authors reviewed, edited and signed off on the final manuscript.

Funding Australian Government Department of Health (4-CKY89XU).

Competing interests SZ, ER and RKD report that the McCabe Centre is a WHO FCTC Knowledge Hub on Legal Challenges and a WHO Collaborating Centre for Law and Non-communicable Diseases, and receives funding from the Australian government for these functions. The McCabe Centre has provided technical support to many of the countries involved in the litigation commented on in this article. DB reports that he is part of the legal team in the Attorney General's Office in the healthcare cost recovery litigation that Brazil has launched against tobacco manufacturers.

Patient consent for publication Not required.

Provenance and peer review Commissioned; externally peer reviewed.

ORCID iD

Suzanne Zhou http://orcid.org/0000-0001-8308-5211

\section{REFERENCES}

1 Campaign for Tobacco Free Kids. Tobacco Control Laws. Available: http://www. tobaccocontrollaws.org/ [Accessed Aug 2021].

2 Campaign for Tobacco Free Kids, International Legal Consortium. Tobacco control laws - major litigation victories. Available: https://www.tobaccocontrollaws.org/ litigation/major_litigation_decisions

3 Zhou S, Liberman J. The global tobacco epidemic and the WHO Framework Convention on Tobacco Control - the contributions of the WHO's first convention to global health law and governance. In: Research handbook on global health law. 1 edn. Edward Elgar Publishing Ltd, 2018: 340-88.

4 Philip Morris Brands Sarl v Uruguay (award) (ICSID arbitral tribunal, ICSID case no ARB/10/7, 8 July 2016). Available: https://www.tobaccocontrollaws.org/litigation/ decisions/uy-20160708-philip-morris-srl-v-uruguay

5 Philip Morris Asia Ltd v Australia (award on jurisdiction and admissibility) (Permanent Court of Arbitration, PCA case no 2012-12, 17 December 2015). Available: https:// www.tobaccocontrollaws.org/litigation/decisions/au-20151217-philip-morris-asia-vaustralia

6 World Trade Organization. Australia - Certain measures concerning trademarks, geographical indications and other plain packaging requirements applicable to tobacco products and packaging. Report of the Appellate Body. WT/DS435/AB/R, WT/ DS441/AB/R (9 June 2020). Available: https://www.wto.org/english/tratop_e/dispu_ e/cases_e/ds435_e.htm; https://www.wto.org/english/tratop_e/dispu_e/cases_e/ ds441_e.htm

7 General Agreement on Tariffs and Trade (1947). Thailand — Restrictions on importation of and internal taxes on cigarettes (5 October 1990, adopted 7 November 1990). Panel Report. DS10/R - 37S/200. Available: https://www.wto.org/ english/tratop_e/dispu_e/gatt_e/90cigart.pdf

8 World Trade Organization. United States - Measures affecting the production and sale of clove cigarettes. Report of the Appellate Body. WT/DS406/AB/R (4 April 2012). Available: https://www.wto.org/english/tratop_e/dispu_e/cases_e/ds406_e.htm

9 JT International SA v Commonwealth (2012) 250 CLR 1. Available: https://www. tobaccocontrollaws.org/litigation/decisions/au-20121005-jt-intl-and-bat-australasia-l

10 McCabe Centre for Law and Cancer. The Australia - plain packaging disputes at the WTO: a summary and stocktake after the final Appellate Body decision. Available: https://www.mccabecentre.org/publications/the-australia-plain-packaging-disputesat-the-wto-a-summary-and-stocktake-after-the-fin.html

11 McCabe Centre for Law and Cancer. The award on the merits in Philip Morris v Uruguay: implications for WHO FCTC implementation. Available: https://www. mccabecentre.org/publications/the-award-on-the-merits-in-philip-morris-v-uruguayimplications-for-who-fctc-implementati.html

12 British American Tobacco Kenya, PLC v Cabinet Secretary for the Ministry of Health (Supreme Court of Kenya, Petition No. 5 of 2017, 26 November 2019). Available: https://www.tobaccocontrollaws.org/litigation/decisions/ke-20191126-britishamerican-tobacco-Itd-v

13 British American Tobacco Ltd v Attorney General and Centre for Health, Human Rights and Development (Constitutional Court of Uganda no 46 of 2016, 28 May 2019). Available: https://www.tobaccocontrollaws.org/litigation/decisions/ug-20190528-batuganda-Itd-v.-attorney-gen

14 JT International (Thailand) v Minister of Public Health, Supreme Administrative Court, Order No. 269/2557, 29 May 2014. Available: https://www.tobaccocontrollaws.org/ litigation/decisions/th-00000000-jti-international-thailand-v.

15 Ceylon Tobacco Company v Minister of Health (Court of Appeal (Sri Lanka), No CA 336/2012 (Writ), 12 May 2014). Available: https://www.tobaccocontrollaws.org/ litigation/decisions/lk-20140512-ceylon-tobacco-v.-minister-of-

16 Philip Morris Brands SARL v Secretary of State for Health (European Court of Justice, Case C-547/14, 4 May 2016). Available: https://www.tobaccocontrollaws.org/ litigation/decisions/eu-20160504-the-queen-on-the-application-0

17 Cabrera OA, Carballo J. Tobacco control litigation: broader impacts on health rights adjudication. J Law Med Ethics 2013;41:147-62 https://pubmed.ncbi.nlm.nih.gov/ 23581663/

18 Dutch Non-Smokers Association CAN (Club of Active Non-Smokers) v Netherlands no 200.205.667/01, 13 February 2018). Available: https://www. tobaccocontrollaws.org/litigation/decisions/nl-20180213-dutch-non-smokersassociation-

19 Murli S Deora v Union of India (2001) 8 SCC 765. Available: https://www. tobaccocontrollaws.org/litigation/decisions/in-20010101-deora-v.-india—ors

20 Love Care Foundation v Union of India (Supreme Court of India, Writ Petition no. 1078 (M/B) of 201321 July 2014)https://www.tobaccocontrollaws.org/litigation/decisions/ in-20140721-love- care-foundation-v.-union

21 Mishra G. 'National green tribunal move on cigarette butts, bidi ends bells smoking's environmental damage', 2020. India Legal. Available: https://www.indialegallive.com/ special-story/national-green-tribunal-cpcb-cigarette-tobacco-bidi-butts-supremecourt/

22 O'Neill Institute for Global and National Health Law. Shadow report to the periodic report by the government of Argentina: challenges in the prevention and reduction of women's tobacco use in Argentina. 46th session, UN Committee on the Elimination of All Forms of Discrimination against Women (shadow report), 2010. Available: https:// tbinternet.ohchr.org/Treaties/CEDAW/Shared\%20Documents/ARG/INT_CEDAW_ NGO_ARG_46_7947_E.pdf

23 Public Health Law Center at Mitchell Hamline School of Law. 'Master settlement agreement'. Available: https://www. publichealthlawcenter.org/topics/commercialtobacco-control/commercial-tobacco-control-litigation/master-settlement-agreement [Accessed 17 Aug 2021].

24 United States v Philip Morris USA, 449 F.Supp.2d 1 (D.D.C. 2006). Available: https:// www.publichealthlawcenter.org/sites/default/files/resources/doj-final-opinion.pdf

25 Campaign for Tobacco Free Kids. Tobacco Control Laws. 'Advanced search: personal injury'. Available: https://www.tobaccocontrollaws.org/litigation/advancedsearch? resultpage $=1$ \&allwords $=$ \&exactword $=\&$ orwords $=\&$ orwords $2=$ \&orwords $3=\&$ dontwords $=\& \mathrm{fctc}=\&$ whoregion $=\&$ country $=\&$ datestart $=\&$ dateen $d=\&$ language $=\&$ type_litigation=Personal+Injury\&subarg=\&type_tobacco=\&mysubmit $=[$ Accessed 17 Aug 2021].

26 Henley J. 'Dutch effort to charge tobacco firms with attempted murder fails', 2018. The Guardian. Available: https://www.theguardian.com/world/2018/feb/22/dutchattempt-to-take-tobacco-firms-to-court-for-manslaughter-fails

27 Comité Nationale Contre le Tabagisme. Filtergate : ouverture d'une enquête préliminaire (Press release, 5 May 2018). Available: https://cnct.fr/communiques/ trous-filtres-enquete-preliminaire/ [Accessed 11 Jun 2021].

28 Létourneau v JTI-MacDonald Corp, 2015 QCCS 2382. Available: https://www.canlii. org/fr/qc/qccs/doc/2015/2015qccs2382/2015qccs2382.html [Accessed 18 Aug 2021].

29 Attorney-General's Office (Brazil). Ação civil pública de tutela do direito fundamental saúde pública e ressarcimento ao erário [Public civil action for the protection of the fundamental right to public health and reimbursement to the Treasury] (written submissions, Federal Court of Rio Grande de Sul, 21 May 2018. Available: https:// www.conjur.com.br/dl/inicial-acp-agu-cigarro.pdf

30 WHO Framework Convention on Tobacco Control Secretariat, World Health Organization. The Secretariat of the WHO FCTC and WHO applaud the Brazilian government's action to seek compensation from tobacco companies (Statement, 23 May 2019). Available: https://www.who.int/fctc/mediacentre/office-attorney-generalbrazil-files-lawsuit-tobacco-industry/en/

31 Zhou SY, Liberman JD, Ricafort E. The impact of the WHO Framework Convention on Tobacco Control in defending legal challenges to tobacco control measures. Tob Control 2019;28:5113-8. 
32 Muggli ME, Zheng A, Liberman J, et al. Tracking the relevance of the WHO Framework Convention on Tobacco Control in legislation and litigation through the online resource, Tobacco Control Laws. Tob Control 2014;23:457-60 https://tobaccocontrol.bmj.com/ content/23/5/457

33 McCabe Centre for Law \& Cancer, WHO Framework Convention on Tobacco Control Secretariat. WHO FCTC Knowledge Hub on legal challenges to implementation of the Convention. Available: www.untobaccocontrol.org/kh/legal-challenges

34 WHO Framework Convention on Tobacco Control Secretariat. Welcome to the article 19 civil liability toolkit. Available: https://untobaccocontrol.org/impldb/tobacco-control-toolkitt\#/
35 Fair-Trade Independent Tobacco Association v President of the Republic of South Africa and another (21688/2020) [2020] ZAGPPHC 246. Available: http://www.saflii. org/za/cases/ZAGPPHC/2020/246.html

36 Philippine Tobacco Institute v City of Balanga, CA-G.R. SP No. 159329, Court of Appeals Manila 15th division, 2019. Available: https://www.tobaccocontrollaws.org/ litigation/decisions/ph-00000000-pti-challenge-to-ordinance-no-

37 World Health Organization. Litigation relevant to regulation of novel and emerging nicotine and tobacco products: comparison across jurisdictions, 2021. Available: https://www.who.int/publications/i/item/9789240020368 